\section{JURNAL EKONOMI EFEKTIF}

ISSN : $2622-8882$, E-ISSN : 2622-9935

Jurnal Ekonomi Efektif, Vol. 4, No. 2, Januari 2022 @Prodi Manajemen Fakultas Ekonomi

Universitas Pamulang

\title{
PENGARUH KEPEMIMPINAN TERHADAP KINERJA KARYAWAN PADA KBMT AL FATH AREA WILAYAH TANGERANG SELATAN
}

\author{
Devit Setyo Utomo ${ }^{1}$, Hadi Supratikta ${ }^{2 *}$ \\ Universitas Pamulang, Tangerang Selatan, Banten, Indonesia \\ $\underline{\text { devitsetyoutomo@gmail.com }}{ }^{1}, \underline{\text { dosen00469@ } \text { unpam.ac.id }^{2 *}}$
}

Manuskrip: Oktober -2021; Ditinjau: November: -2021; Diterima: November-2021; Online: Januari -2022; Diterbitkan: Januari-2022

\begin{abstract}
ABSTRAK
Penelitian ini bertujuan untuk mengetahui pengaruh kepemimpinan terhadap kinerja karyawan pada KBMT Al Fath Area Wilayah Tangerang Selatan. Metode yang digunakan adalah explanatory research dengan sampel sebanyak 85 responden. Teknik analisis menggunakan analisis statistik dengan pengujian regresi, korelasi, determinasi dan uji hipotesis. Hasil penelitian ini variabel kepemimpinan diperoleh nilai rata-rata skor sebesar 3,811 dengan kriteria baik. Variabel kinerja karyawan diperoleh nilai rata-rata skor sebesar 3,911 dengan kriteria baik. Kepemimpinan berpengaruh positif dan signifikan terhadap kinerja karyawan dengan nilai persamaan regresi $\mathrm{Y}=9,701+0,326 \mathrm{X}$, dan nilai koefisien korelasi 0,649 atau memiliki tingkat hubungan yang kuat dengan nilai determinasi $42,1 \%$. Uji hipotesis diperoleh signifikansi $0,000<0,05$.
\end{abstract}

\section{Kata Kunci: Kepemimpinan, Kinerja Karyawan}

\begin{abstract}
This study aims to determine the influence of leadership on employee performance at KBMT Al Fath Area South Tangerang. The method used is explanatory research with a sample of 85 respondents. The analysis technique uses statistical analysis with regression, correlation, determination and hypothesis testing. The results of this study of leadership variables obtained an average score of 3.811 with good criteria. Employee performance variable obtained an average score of 3.911 with good criteria. Leadership has a positive and significant effect on employee performance with a regression equation value of $Y=9.701+0.326 X$, and a correlation coefficient value of 0.649 or has a strong relationship with a determination value of $42.1 \%$. Hypothesis testing obtained a significance of $0.000<0.05$.
\end{abstract}

Keywords: Leadership, Employee Performance 


\section{PENDAHULUAN}

\section{A. Latar Belakang}

Dalam dewasa ini di Indonesia banyak bermunculan usaha-usaha kecil menengah. Banyaknya usaha kecil menengah seperti koperasi dapat memberikan pengaruh bertambahnya lapangan pekerjaan bagi masyarakat Indonesia. Dari sisi lain koperasi tidak mungkin mengelola kegiatannya tanpa dukungan sumber daya manusia, karena faktor sumber daya manusia memegang peranan yang sangat penting dalam pencapaian tujuan koperasi.

Faktor sumber daya manusia merupakan tumpuan bagi koperasi untuk tetap dapat bertahan di era globalisasi. Sumber daya manusia memegang peranan penting dalam setiap pengelolaan koperasi. Dalam hal ini bahwa sumber daya manusia adalah kunci utama yang harus dapat perhatian penuh dengan semua kebutuhannya. Sebagai kunci utama, sumber daya manusia dapat menentukan keberhasilan dalam pengelolaan koperasi.

Sumber daya manusia adalah penggerak koperasi sehingga banyak dipengaruhi oleh para pesertanya (partisipannya). Keanggotaan sumber daya manusia dalam koperasi diatur dengan adanya pemberian wewenang dan tanggung jawab dalam pengelolaan kegiatan. Merumuskan wewenang dan tanggung jawab yang harus dicapai oleh organisasi ditetapkan dengan standar atau tolak ukur yang telah disepakati oleh karyawan dan pimpinan.

Pemimpin merupakan bagian dari proses pengembangan sumber daya manusia, dimana sumber daya manusia merupakan asset dari sebuah organisasi atau perusahaan yang apabila dikelola secara tepat maka akan memberikan nilai tambah bagi perusahaannya. Selain itu pemimpin juga memegang peran kunci dalam memformasikan strategi organisasi, sehingga peranannya akan mempengaruhi keberhasilan organisasi, tidak terkecuali pengaruh kepemimpinan pada Baitul Maal Wat Tamwil yang lebih populer dikenal dengan sebutan BMT. Dimana sama halnya dengan perusahaan menengah atau koperasi pada umumnya di dalam BMT sendiri pengaruh kepemimpinan sangatlah sangat menentukan didalam arah perkembangan perusahaan.

Seorang pemimpin tidak hanya dituntut untuk tegas dan sigap dalam menghadapai setiap persoalan yang ada, melainkan juga harus mengerti akan keinginan atau setiap kebutuhan karyawannya. Pemimpin yang bijaksana dan baik harus dapat memberikan kepuasan kepada para bawahannya dan selalu berusaha memperhatikan gairah serta semangat kerja mereka. Tentunya pihak pimpinan harus mempunyai kemampuan dalam mengatur, mengelola, mengarahkan, mempengaruhi, memerintah dan memotivasi bawahannya untuk memperoleh tujuan yang diinginkan oleh organisasi.

Alasan yang menjadi dasar dari penelitian ini adalah bahwa sumber daya manusia mempunyai peranan yang sangat penting di dalam suatu perusahaan. Untuk itu peneliti memilih judul pengaruh kepemimpinan terhadap kinerja karyawan. Dimana dalam suatu perusahaan sumber daya manusia yang terdiri dari pemimpin dan karyawan merupakan suatu permasalahan dan penentu keberhasilan bagi perusahaan. Selain itu pemimpin melalui penerapan kepemimpinannya memiliki pengaruh yang sangat besar bagi perusahaan yang dipimpinnya dan setiap kebijakan-kebijakan yang dikeluarkannya akan mempengaruhi kualitas kinerja yang dihasilkan oleh karyawannya. Terkadang seorang pemimpin lupa akan komponen yang ada disekitarnya, sehingga yang tercipta rasa tidak nyaman di dalam komponen perusahaan tersebut. Hal ini akan berdampak pada perusahaannya, karena suatu perusahaan dapat berkembang semakin maju juga disebabkan dengan adanya sinergisitas yang baik dalam perusahaan itu sendiri.

Dengan demikian kiranya perlu diupayakan terus kinerja karyawan melalui 
kepermimpinan di KBMT Al Fath Area Wilayah Tangerang Selatan. Jadi berdasarkan latar belakang diatas, maka penulis tertarik untuk mengadakan penelitian yang berkaitan dengan kepemimpinan pada KBMT Al Fath Area Wilayah Tangerang Selatan dengan judul "Pengaruh Kepemimpinan terhadap Kinerja Karyawan Pada KBMT Al Fath Area Wilayah Tangerang Selatan"

\section{B. Rumusan Masalah}

1. Bagaimana kepemimpinan pada KBMT Al Fath Area Wilayah Tangerang Selatan ?.

2. Bagaimana kinerja karyawan pada KBMT Al Fath Area Wilayah Tangerang Selatan?

3. Adakah pengaruh antara kepemimpinan terhadap kinerja karyawan pada KBMT Al Fath Area Wilayah Tangerang Selatan?.

\section{Tujuan Penelitian}

1. Untuk mengetahui kondisi kepemimpinan pada KBMT Al Fath Area Wilayah Tangerang Selatan.

2. Untuk mengetahui kondisi kinerja karyawan pada KBMT Al Fath Area Wilayah Tangerang Selatan.

3. Untuk mengetahui pengaruh kepemimpinan terhadap kinerja karyawan pada KBMT Al Fath Area Wilayah Tangerang Selatan.

\section{TINJAUAN PUSTAKA}

\section{Kepemimpinan}

Definisi kepemimpinan menurut Sudaryono (2019:8) "Kepemimpinan adalah setiap perbuatan yang ditentukan oleh individu atau kelompok untuk mengkoordinasi dan memberi arah kepada individu atau kelompok yang tergabung didalam wadah tertentu untuk mencapai tujuan yang telah ditetapkan sebelumnya“.

\section{Kinerja Karyawan}

Menurut Mangkunegara (2019:75) pengertian kinerja adalah hasil kerja secara kualitas dan kuantitas yang dicapai oleh seorang pegawai dalam melaksanakan tugasnya sesuai dengan tanggung jawab yang diberikan kepadanya.

\section{III.METODE PENELITIAN}

\section{Populasi}

Yang dijadikan sebagai populasi dalam penelitian ini adalah responden yang berjumlah 85 responden KBMT Al Fath Area Wilayah Tangerang Selatan

\section{Sampel}

Teknik pengambilan sampling dalam penelitian ini adalah sampel jenuh, dimana semua anggota populasi dijadikan sebagai sampel. Dengan demikian sampel dalam penelitian ini sampel yang digunakan berjumlah 85 responden.

\section{Jenis Penelitian}

Jenis penelitian yang dipakai adalah asosiatif, dimana tujuannya adalah untuk mengetahui atau mencari keterhubungan antara variabel independen terhadap variabel dependennya

\section{Metode Analisis Data}

Dalam menganalisis data digunakan uji validitas, uji reliabilitas, analisis regresi linier sederhana, analisis koefisien korelasi, analisis koefisien determinasi dan pengujian hipotesis. 


\section{IV.HASIL PENELITIAN}

\section{Analisis Deskriptif}

Pada pengujian ini digunakan untuk mengetahui skor minimum dan maksimum skor tertinggi, ratting score dan standar deviasi dari masing-masing variabel. Adapun hasilnya sebagai berikut:

Tabel 1. Hasil Analisis Descriptive Statistics

Descriptive Statistics

\begin{tabular}{lr|r|r|r|r} 
& N & Minimum & Maximum & Mean & Std. Deviation \\
\hline Kepemimpinan (X) & 86 & 32 & 48 & 38.15 & 4.019 \\
\hline Kinerja Karyawan (Y) & 86 & 32 & 47 & 39.06 & 3.499 \\
\hline Valid N (listwise) & 86 & & & & \\
\hline
\end{tabular}

Kepemimpinan diperoleh varians minimum sebesar 32 dan varians maximum 48 dengan ratting score sebesar 3,811 dengan standar deviasi 4,019. Skor ini termasuk pada rentang sakala 3,40 - 4,19 dengan kriteria baik atau setuju. Kinerja karyawan diperoleh varians minimum sebesar 32 dan varians maximum 47 dengan ratting score sebesar 3,911 dengan standar deviasi 3,499. Skor ini termasuk pada rentang sakala 3,40 $-4,19$ dengan kriteria baik atau setuju.

\section{Analisis Kuantitatif}

Pada analisis ini dimaksudkan untuk mengetahui pengaruh variabel independen terhadap variabel dependen. Adapun hasil pengujian sebagai berikut:

\section{a. Analisis Regresi Linier Sederhana}

Uji regresi ini dimaksudkan untuk mengetahui perubahan variabel dependen jika variabel independen mengalami perubahan. Adapun hasil pengujiannya sebagai berikut:

\begin{tabular}{|c|c|c|c|c|c|}
\hline \multirow[b]{3}{*}{ Model } & \multicolumn{2}{|c|}{ Coefficients ${ }^{\mathrm{a}}$} & \multirow[b]{2}{*}{$\begin{array}{l}\text { Standardized } \\
\text { Coefficients }\end{array}$} & \multirow[b]{3}{*}{$\mathrm{t}$} & \multirow[b]{3}{*}{ Sig. } \\
\hline & \multicolumn{2}{|c|}{$\begin{array}{l}\text { Unstandardized } \\
\text { Coefficients }\end{array}$} & & & \\
\hline & B & Std. Error & Beta & & \\
\hline 1 (Constant) & 9.701 & 2.352 & & 3.762 & .000 \\
\hline Kepemimpinan (X) & .326 & .068 & .787 & 7.809 & .000 \\
\hline
\end{tabular}

Berdasarkan hasil pengujian pada tabel di atas, diperoleh persamaan regresi $\mathrm{Y}$ $=9,701+0,326 \mathrm{X}$. Dari persamaan tersebut dijelaskan sebagai berikut:

1) Konstanta sebesar 9,701 diartikan jika kepemimpinan tidak ada, maka telah terdapat nilai kinerja karyawan sebesar 9,701 point.

2) Koefisien regresi kepemimpinan sebesar 0,326, angka ini positif artinya setiap ada peningkatan kepemimpinan sebesar 0,326 point maka kinerja karyawan juga akan mengalami peningkatan sebesar 0,326 point.

\section{b. Analisis Koefisien Korelasi}

Analisis koefisien korelasi dimaksudkan untuk mengetahui tingkat kekuatan hubungan dari variabel independen terhadap variabel dependen. Adapun hasil pengujian sebagai berikut: 
Tabel 3. Hasil Pengujian Koefisien Korelasi Kepemimpinan Terhadap Kinerja

Karyawan.

Correlations $^{\mathrm{b}}$

\begin{tabular}{llr|r} 
& & $\begin{array}{c}\text { Kepemimpinan } \\
(\mathrm{X} 1)\end{array}$ & $\begin{array}{r}\text { Kinerja Karyawan } \\
(\mathrm{Y})\end{array}$ \\
\hline Kepemimpinan $(\mathrm{X})$ & Pearson Correlation & 1 & $.649^{* * *}$ \\
\cline { 2 - 4 } & Sig. (2-tailed) & & .000 \\
\hline Kinerja Karyawan (Y) & Pearson Correlation & $.649^{* *}$ & 1 \\
\cline { 2 - 4 } & Sig. (2-tailed) & .000 & \\
\hline
\end{tabular}

Berdasarkan hasil pengujian diperoleh nilai korelasi sebesar 0,649 artinya kepemimpinan memiliki hubungan yang kuat terhadap kinerja karyawan.

\section{c. Analisis Koefisien Determinasi}

Analisis koefisien determinasi dimaksudkan untuk mengetahui besarnya persentase pengaruh dari variabel independen terhadap variabel dependen. Adapun hasil pengujian sebagai berikut:

Tabel 4. Hasil Pengujian Koefisien Determinasi Kepemimpinan Terhadap Kinerja Karyawan.

\begin{tabular}{|c|c|c|c|c|}
\hline \multicolumn{5}{|c|}{ Model Summary } \\
\hline Model & $\mathrm{R}$ & R Square & $\begin{array}{l}\text { Adjusted R } \\
\text { Square }\end{array}$ & $\begin{array}{l}\text { Std. Error of the } \\
\text { Estimate }\end{array}$ \\
\hline 1 & $.649^{\mathrm{a}}$ & .421 & .414 & 2.679 \\
\hline
\end{tabular}

Berdasarkan hasil pengujian diperoleh nilai determinasi sebesar 0,421 artinya kepemimpinan memiliki kontribusi pengaruh sebesar $42,1 \%$ terhadap kinerja karyawan, sedangkan sisanya sebesar 57,9\% dipengaruhi oleh faktor lain yang tidak dilakukan penelitian.

\section{d. Uji Hipotesis}

Pengujian hipotesis dengan uji t digunakan untuk mengetahui hipotesis mana yang diterima. Rumusan hipotesis: Terdapat pengaruh yang signifikan kepemimpinan terhadap kinerja karyawan.

Tabel 5. Hasil Uji Hipotesis Kepemimpinan Terhadap Kinerja Karyawan.

\begin{tabular}{lr|r|r|r|r} 
& \multicolumn{2}{c}{$\begin{array}{c}\text { Coefficients } \\
\text { Unstandardized } \\
\text { Coefficients }\end{array}$} & $\begin{array}{c}\text { Standardized } \\
\text { Coefficients }\end{array}$ & & \\
Model & $\mathrm{B}$ & Std. Error & \multicolumn{1}{c|}{ Beta } & \multicolumn{1}{c|}{$\mathrm{t}$} & \multicolumn{1}{c}{ Sig. } \\
\hline 1 (Constant) & 9.701 & 2.352 & & 3.762 & .000 \\
\hline Kepemimpinan $(\mathrm{X})$ & .326 & .068 & .787 & 7.809 & .000 \\
\hline
\end{tabular}

Berdasarkan hasil pengujian pada tabel di atas, diperoleh nilai t hitung $>\mathrm{t}$ tabel atau $(7,809>1,989)$, dengan demikian hipotesis yang diajukan bahwa terdapat pengaruh yang signifikan atara kepemimpinan terhadap kinerja karyawan diterima.

\section{Pembahasan Hasil Penelitian}

\section{Kondisi Jawaban Responden Variabel Kepemimpinan}

Berdasarkan jawaban responden, variabel kepemimpinan diperoleh ratting score sebesar 3,811 berada di rentang skala 3,40-4,19 dengan kriteria baik atau setuju.

\section{Kondisi Jawaban Responden Variabel Kinerja Karyawan}

Berdasarkan jawaban responden, variabel kinerja karyawan diperoleh ratting score sebesar 3,911 berada di rentang skala 3,40 - 4,19 dengan kriteria baik atau setuju. 


\section{Pengaruh Kepemimpinan Terhadap Kinerja Karyawan}

Kepemimpinan berpengaruh signifikan terhadap kinerja karyawan dengan persamaan regresi $\mathrm{Y}=9,701+0,326 \mathrm{X}$, nilai korelasi sebesar 0,649 atau memiliki hubungan yang kuat dengan kontribusi pengaruh sebesar 42,1\%. Pengujian hipotesis diperoleh nilai $\mathrm{t}$ hitung $>\mathrm{t}$ tabel atau $(7,809>1,989)$. Dengan demikian hipotesis yang diajukan bahwa terdapat berpengaruh signifikan antara kepemimpinan terhadap kinerja karyawan diterima.

\section{KESIMPULAN DAN SARAN}

\section{Kesimpulan}

a. Variabel kepemimpinan diperoleh ratting score sebesar 3,811 berada di rentang skala 3,40 - 4,19 dengan kriteria baik atau setuju.

b. Variabel kinerja karyawan diperoleh ratting score sebesar 3,911 berada di rentang skala 3,40-4,19 dengan kriteria baik atau setuju.

c. Kepemimpinan berpengaruh signifikan terhadap kinerja karyawan dengan persamaan regresi $\mathrm{Y}=9,701+0,326 \mathrm{X}$, nilai korelasi sebesar 0,649 atau kuat dan kontribusi pengaruh sebesar $42,1 \%$ sedangkan sisanya sebesar 57,9\% dipengaruhi faktor lain. Uji hipotesis diperoleh nilai $t$ hitung $>t$ tabel atau $(7,809>1,989)$.

\section{Saran}

a. Pimpinan perlu menyesuaikan gaya kepemimpinannya dengan situasi yang di hadapi baik dari karakteristik karyawan, pengetahuan, dan kemampuan karyawan.

b. Kepemimpinan merupakan hal yang sangat penting dalam suatu perusahaan dalam meningkatkan kinerja para karyawannya, diharapkan pimpinan dapat memberikan pengarahan yang baik dan berkelanjutan sehinga para karyawannya merasa dihargai dan merasa nyaman dalam bekerja dan dapat mencurahkan perhatiannya pada pekerjaannya. Pimpinan hendaknya memberikan bimbingan dan perhatian yang lebih kepada karyawan sehingga mereka akan menghasilkan pekerjaan dengan tujuan bahwa kepentingan perusahaan adalah kepentingan mereka juga.

c. Keberhasilan perusahaan pada dasarnya di topang oleh kepemimpinan yang efektif, dimana dengan kepemimpinannya itu dapat mempengaruhi bawahannya untuk membangkitkan motivasi kerja dan kinerja mereka agar berprestasi terhadap tujuan bersama.

\section{DAFTAR PUSTAKA}

Aden, Widjan dkk, "Studi Kepemimpinan Islam", Pusat Studi Islam UII, Yogyakarta, 2004.

Ahmad Fadli, "Pengaruh gaya kepemimpinan terhadap kinerja karyawan pada PT Kawasan industri” Medan, diakses dari http://library.usu.ac.id. 2002.

As'ad, M., "Psikologi Industri” Edisi Keempat, Liberty, Yogyakarta, 2004 Aunur, Rohim F dan Iip Wijayanto, "Kepemimpinan Islam”, UII Press, Yogyakarta, 2001.

Gibson, James L et al, "Organisasi dan Manajemen: Perilaku, Struktur, Proses”, Edisi Keempat, Terjemahan, Erlangga, Jakarta, 2001.

Hariandja, Marihot Tua Efendi, "Manajemen Sumber Daya Manusia: Pengadaan, Pengembangan,Pengkompensasian, dan Peningkatan Produktivitas Pegawai", Cetakan ketiga, PT Grasindo, Jakarta, 2005.

Hasibuan, Malayu SP. “Organisasi dan Motivasi Dasar Peningkatan Produktifitas”, Bumi Aksara, Jakarta, 2000.

Imam Moedjiono, “Kepemimpinan dan Keorganisasian”, UII Press, Yogyakarta, 2002. 
Iswanto, Yun, “Manajemen Sumber Daya Manusia”, Universitas Terbuka, Jakarta, 2006. Kamus Besar Bahasa Indonesia Edisi ketiga, Balai Pustaka, Jakarta, 2001.

Kartono, Kartini, "Pemimpin dan Kepemimpinan", Edisi Kedua, Cetakan Kesembilan, RajaGrafindo Persada, Jakarta, 2003.

Mangkunegoro, Anwar Prabu, “Manajemen Sumber Daya Manusia Perusahaan”, Remaja Rosdakarya, Bandung, 2001

Manullang, M., "Manajemen Personalia”, Ghalia Indonesia, Medan, 2004.

Mathis, Robert. L dan Jackson John H., "Manajemen Sumber Daya Manusia”, Edisi Pertama, Salemba Empat, Jakarta, 2002.

Notoatmodjo, Soekidjo, "Pengembangan Sumber Daya Manusia", Cetakan Ketiga, Rineka Cipta, Jakarta, 2003.

Pandji Anoraga, "Bumn, Swasta dan Koperasi”, Gramedia Utama, Jakarta, 2000.

Robbins, Stephen P., "Perilaku Organisasi”, Edisi Kesepuluh, Indeks, Jakarta, 2006.

Saydam, Gouzali, "Manajemen Sumber Daya Manusia: Suatu pendekatan Mikro", Cetakan kedua, Djambatan, Jakarta, 2000.

Siagian, Sondang P., "Manajemen Sumber Daya Manusia”, Cetakan ketiga belas, Bumi Aksara, Jakarta, 2006.

Sugiyono, "Metode Penelitian Kuantitatif dan Kualitatif $R \& D$ ", Alfabeta, Bandung, 2006.

Veitzhal Rivai, “Kepemimpinan dan Perilaku Organisasi”. Rajagravindo Persada, 2008 